\title{
TEACHING SERBIAN LEARNERS ENGLISH PHRASAL VERBS: THE TRADITIONAL APPROACH VS. THE COGNITIVE LINGUISTIC APPROACH ${ }^{1}$
}

\begin{abstract}
This study examines the results obtained by using the traditional and the cognitive approach to teaching phrasal verbs. The control group was taught phrasal verbs using the traditional way i.e. by providing a direct translation into Serbian. In the experimental group the author presented the verbs by explaining the meanings of the very particles and the meanings they develop. Both groups were given a test immediately after they received input. They were also tested on the meanings of untaught phrasal verbs three weeks later. Utilising the cognitive approach helped the students learn the phrasal verbs more successfully. The students who knew various meanings of the particles were able to understand the meanings of the whole phrasal verbs better. The experimental group was able to predict the meanings of the untaught phrasal verbs in the delayed test better than the control group.
\end{abstract}

Keywords: phrasal verbs, particles, traditional approach, cognitive approach, translation, retention, metaphorical conceptualisation, opaque meaning, transparent meaning.

\footnotetext{
1 This paper is a shorter version of a seminar paper that was submitted in fulfillment of the requirements for the exam The Contrastive Analysis of Language at the Faculty of Philosophy in Novi Sad (doctoral studies). It was written under the mentorship of Professor Predrag Novakov, $\mathrm{PhD}$.
} 


\title{
PODUČAVANJE SRPSKIH UČENIKA ENGLESKIM FRAZNIM GLAGOLIMA: TRADICIONALNI PRISTUP U KONTRASTU SA PRISTUPOM KOGNITIVNE LINGVISTIKE
}

\begin{abstract}
APSTRAKT
Ovo istraživanje istražuje rezultate dobijene upotrebom tradicionanog pristupa i kognitivnolingvističkog pristupa u nastavi fraznih glagola. U kontrolnoj grupi korišćen je tradicionalni pristup u podučavanju fraznih glagola - istraživač je davao direktne prevode za ove jedinice, bez obaziranja na osnovno (dubinsko) značenje partikula. U eksperimentalnoj grupi istraživač je predstavio frazne glagole sa akcentom na značenje samih partikula i traženjem veze između osnovnog i njegovih izvedenih značenja. Obe grupe su testirane neposredno nakon inputa, ali i nakon tri nedelje kako bi se ustanovilo razumevanje neobrađenih fraznih glagola. Polaznici su uspešnije savladali frazne glagole kad su bili podučavani kognitivističkim metodom (i dugoročno i kratkoročno). Polaznici kojima je skrenuta pažnja na raznovrsna značenja partikula mogli su bolje da razumeju značenje fraznih glagola kao celine. Eksperimentalna grupa, koja je bila podvrgnuta kognitivističkom pristupu, mogla je bolje da prepozna značenje nepoznatih fraznih glagola.
\end{abstract}

Ključne reči: frazni glagoli, partikule, tradicionalni pristup, kognitivistički pristup, prevođenje, metaforička konceptualizacija, neprozirno značenje, prozirno značenje.

\section{INTRODUCTION}

Phrasal verbs seem to pose a problem in the classroom and deserve more attention and a specially devised approach. One of the reasons why they are challenging might lie in the fact that they are often covered in class in an inappropriate manner. They are often regarded by teachers as units that cannot be mastered by using any logic. Serbian translations are provided to the students without any consideration of the meanings that the elements of these units have. However, there are alternatives to the traditional approach to teaching them. The cognitive approach attempts to go into the developed and abstract meanings of the particles and link them to the basic and more literal (physical) meanings that the particles have in isolation.

The aim of this research is to see how the students manage to understand and remember familiar and unfamiliar phrasal verbs, focusing primarily on the particles. Both the traditional and cognitive approach to teaching phrasal verbs will be put to use. It is expected that the modern (cognitive) approach will be 
more appealing to the students and that it will help them master these units more successfully.

The first hypothesis regarding the research is that the learners are able to better comprehend and memorise the meanings of both separate particles and whole phrasal verbs when they are taught by means of the cognitive linguistic approach. The second hypothesis that is intricately connected to the previous one is that if the students are more aware of the possible meanings of the particles in phrasal verbs, they will automatically be able to perform better in understanding the meaning of the whole phrasal verb. The third hypothesis is that the performance of the experimental group will be better than that of the control group when both groups are given a test with untaught (unfamiliar) phrasal verbs, assuming that the experimental group will apply the cognitive linguistic approach.

The research by Ganji (2011) deals with the same subject matter. Fortyfive Iranian EFL university students took part in the research that he conducted (Ganji 2011: 1497). The primary aim of the study was to establish the importance of metaphors in the process of memorisation, retention and prediction of the meanings of a certain number of phrasal verbs. In the control group, the students were provided with L1 equivalents of English phrasal verbs in order to simulate a traditional approach. The aim in the experimental groups was to present these units by using the cognitive linguistic approach. The experimental group was given orientational metaphors hidden behind the meanings of the particles that constituted the phrasal verbs. All the students were given the same test in which they were asked to provide the appropriate particle for each phrasal verb. The first test was given to all the students two hours after they had finished the class. The same test was given to them five weeks later. The third one that they did contained 20 untaught phrasal verbs which consisted of the same particles as the ones that they had previously done. The results on the immediate test did not significantly differ, while there was a considerable difference in the test results obtained in the delayed and untaught test. The students in the experimental group scored fairly better than the ones in the control group.

Ganji (2011: 1503) concludes that if the teacher is particularly interested in the students memorising the meanings of phrasal verbs in the short run, providing a translation can be effective. However, if the primary objective is to improve students' ability to retain the meanings of phrasal verbs in the long run, then metaphoric conceptualisation plays a key role. The Iranian author also states that the unpredictable nature of unfamiliar phrasal verbs can be overcome by taking into account the usual meaning of the particle and trying to find the 
metaphoric meaning that is transferred from the more literal to the more abstract meanings.

\subsection{Phrasal verbs}

When it comes to the linguistic phenomenon of phrasal verbs, they can be understood as types of verbs that are comprised of a sequence of lexical elements combined with either one or more adverbial or prepositional particles (Crystal 1980: 170). This is the definition that will be used for the purposes of this work. According to the Cambridge International Dictionary of Phrasal Verbs (1997: 1), phrasal verbs are not merely an integral part of everyday and informal language, but they can also be found in written and formal texts. The same source also points out how difficult they might be to learn due to the fact that the meaning of the whole phrasal verb as a unit can be completely unrelated to the meaning of the constituents (verb and particle) or because even the slightest change in the use of the particle can result in a complete change in the meaning of the phrasal verb.

\subsection{The traditional approach}

When analysing the traditional approach to teaching phrasal verbs, one must consult what grammarians of the 1970s and 1980s thought about the issue at hand. In her observation of the matter, Kovacs (2011: 143) draws attention to grammarians such as Bolinger, Lipka, Sroka and Fraser and states that their perception of phrasal verbs is that of units which are arbitrarily comprised of a verb and particle. She also points out that these authors usually discuss phrasal verbs from the perspective of their syntactic properties, whereas no attention is dedicated to linguistic meaning, except for spatial and aspectual meaning. Kovacs (2011: 144) lists grammarians such as Lindner, Lakoff, Rudzka-Ostyn, Tyler and Evans, who claim that the meaning of the particles is rather like a network of senses that are intricately intertwined and that phrasal verbs can be presented to learners in a more systematic and analysable fashion. To illustrate some of the misconceptions that exist among the majority of traditionalist teachers and learners about the nature of phrasal verbs, Marks (2005, as cited in Kovacs 2011: 141) names some of them. Firstly, he states that phrasal verbs are illogical to a great extent, along with being random and unpredictable in their meaning and word combinations. Secondly, he points out their uniqueness to English and, therefore, it is difficult to compare them as a linguistic phenomenon to other 
languages. Another observation is the insistence on phrasal verbs being colloquial and informal in style and thus of less importance for discussion, which diverts the learners' attention away from them. Related to this is the assumption that all phrasal verbs have their proper equivalents which are in nature non-phrasal.

\subsection{The cognitive linguistic approach}

Evans et al. (2007: 2) say that cognitive linguistics is a modern school of thought and practice that focuses on trying to examine the relationship that exists between the human language, mind and experience.

Kovacs (2011: 146) summarises the words of cognitive linguists by saying that, in phrasal verbs, the meanings can range from a more concrete reference to a more abstract one, and that what actually links these meanings is metaphor. She adds that this link is at times unnoticeable for foreign learners and that they are incapable of identifying the metaphor that lies behind the abstract meaning. She provides a couple of instances of phrasal verbs which can be used both literally and abstractly in order to exemplify the intentions of this more modern approach to linguistics. The example that she uses is of dogs digging up a bone and of a fact being dug up. However, this is obviously not going to pose such a problem for learners as the connection is quite transparent. Moon (2005, as cited in Kovacs 2011: 147) deals with the phenomenon of those particles that are used metaphorically. She focuses on phrasal verbs with such particles to highlight the fact that the cognitive linguistic approach can play a key role in bridging the differences between the literal and metaphorical meanings of particles. To illustrate this, Moon (2005, as cited in Kovacs 2011: 147) discusses the particle $u p$, which literally denotes an upward movement, whereas metaphorically, it can refer to an increase in size, number or strength (e.g. went up).

According to Tyler and Evans (2004: 261), there is a polysemy network that is based on one key sense instead of there being a list of meanings that are not related. To further illustrate the core of the cognitive approach, Morgan (1997: 355) further expands metaphoric interpretations by saying that the different meanings of particles and phrasal verbs are just metaphorical extensions of one meaning. 


\section{RESEARCH METHODOLOGY}

\subsection{Participants}

Twenty participants were tested in this research. All of them attended lessons of English in a private language school in Novi Sad, Serbia. All twenty participants had their regular lessons with their teacher (the author of this study), twice a week. These lessons lasted 90 minutes, or 180 minutes per week. The students had all previously completed the B1 level of English and were attending the upper-intermediate (B2) level of English. This level was chosen for the research of phrasal verbs because they were already familiar with such a linguistic phenomenon.

\subsection{Research design}

When it comes to the nature of this study, it is quasi-experimental due to the fact that the participants were taken from the already existing groups of the B2 level. In other words, the choice of the students was not random and they all attended the same private school and were taught by the same teacher. These students were taught English in two different groups, but all the students were officially at the same level of knowledge. Both the experimental and control group consisted of 10 students each. In the control group, the students were taught by means of the traditional approach. In the experimental group, the students were subjected to the cognitive linguistic approach. They were told about the semantic similarities that exist between the primary meanings of particles in isolation and the developed meanings of the particles used in the chosen phrasal verbs. These developed meanings were traced back to the primary ones and the aim was to understand the logic behind those phrasal verbs that were more idiomatic. To figure out was not merely explained as to discover or understand, but was rather broken down into its pieces, with the abstract meaning reconstructed to its essence. The particle out was explained as leaving one's field of current knowledge in order to expand it. This leaving process is similar to the outward direction that the particle implies in its primary meaning, which makes sense to the students and facilitates the learning process. The following phrasal verbs were included in the test: cross out, stick out, draw out, die out, work out, eat out, chip in, take in, kick in, break in, bring out, figure out, set in, branch out and muck in. 


\subsection{Instrumentation}

The students of both the control and experimental group were given a test immediately after they were taught in their respective ways. This was the immediate test. It consisted of two different papers. In the first paper, the students were asked to read ten sentences in which the particles were put in bold. In each of these ten sentences, there was one phrasal verb. The multiple-choice question that was provided for each sentence enquired about the meaning of the very particle in the phrasal verb, with four options given. On completing that, the students were given another paper (test) which consisted of only five sentences, each containing one phrasal verb. The focus was on the whole unit in this second test. The questions were of a multiple-choice nature, offering four options. Twenty days after taking the first test (its two parts), the students of both groups were given the delayed test. They were expected to guess the meanings of untaught phrasal verbs that contained the same particles as all the other ones from the previous test. The purpose of the immediate test was to see how well the students understood the covered units, while the point of the delayed test was to ascertain their ability to retain new units and deal with unfamiliar ones.

\subsection{Data collection procedure}

The students of both groups received a prepared text with ten phrasal verbs. The phrasal verbs were subsequently discussed one by one. The students were asked by the teacher to come up with the adequate Serbian translations. They were guessing from the context and heavily relying on the meaning of the verbal part. No time was spent going into the meanings of the particles within the phrasal verbs. Once the translations of the phrasal verbs were written on the whiteboard, the students were given two papers, one after the other. On the first paper (part 1) of the immediate test, the students had to answer 10 questions about the meanings of the particles in 10 phrasal verbs in a context. The two particles which were provided were in an out. In the delayed test, which the students did 20 days later, the students were required to guess the meanings of 5 unfamiliar phrasal verbs.

In the experimental group, the teacher did not try to elicit a Serbian equivalent for each verb. Each verb was analysed by paying special attention to the meaning of the particle in each phrasal verb and by looking for either an English synonym or short descriptive definition of the whole unit. When the 
various meanings of the particles were analysed separately and written on the board, the following step was to draw the students' attention to the fact that these meanings were inherently connected and that they were merely metaphorical extension of a more physical concept. To further illustrate and clarify this, the meaning of the particle out was first narrowed down to its physical and literal meaning which implies the physical distance from something. This meaning was further expanded into the other ones in such a way that they could comprehend this internal connection between these meanings. The aim of the teacher was to show that extinction, exclusion, extension, appearance and mental distance were all actually conceptually connected to the idea of physical distance. The same was done with the particle in and its meanings.

\section{RESULTS, ANALYSIS AND DISCUSSION}

This section of the study deals with the findings that were compiled after the students had taken the two tests. Particular students will be addressed under the name of $\mathrm{C} 1, \mathrm{C} 2, \mathrm{C} 3$ etc. (for students from the control group), whereas the students from the experimental group will be referred to as E1, E2, E3 etc. The correct answers will be provided in bold.

\subsection{The immediate test}

\subsubsection{The control group (part 1)}

In part 1 of the test, exercise number 1 , the students chose among 4 answers for each question. With regard to the particle out, which was used 6 times in the phrasal verbs, these were all the options that were used as the definitions of the particle: 1) exclusion 2) appearance 3) extension 4) extinction 5) mentally going beyond 6) physically outside.

It is of great importance to note that the possible meanings of the particles at hand were not discussed in class, nor were they in any way associated with any metaphorical meaning that they could have in these phrasal verbs. However, the examiner made sure that the students were at least familiar with the meanings of the English words used in the four options.

The sentences (questions) that the students got in part 1 were as follows:

1. If you make a mistake, just cross it out.

a) exclusion b) appearance c) extinction d) extension 
Sixty percent of the students managed to answer the question correctly. The meaning of this particle is not so transparent (literal) and if this fact is taken into account, the percent of the correct answers is not considered to be low.

2. She's new to the job and it really sticks out.

a) exclusion $\boldsymbol{b}$ ) appearance c) extinction d) extension

The meaning of the particle was more abstract. Fifty percent of the students answered this question correctly.

3. The director drew the meeting out for another hour with a series of tedious questions.

a) exclusion b) appearance c) extinction d) extension

The percentage of those who answered correctly was unexpectedly high (60\%), bearing in mind that the meaning of this particle is quite abstract. The students conceivably managed to understand the proper meaning by relying on the context.

4. Many of the customs of village life have died out over the years.

a) exclusion b) appearance c) extinction d) extension

The meaning of the particle is quite opaque but it seemed to have been fairly easy for the students, since $70 \%$ were correct. The students were able to answer correctly probably by taking into account the meaning of the verbal part.

5. We couldn't work out why they looked so guilty.

a) exclusion b) appearance c) physically outside d) mentally go beyond

Only $30 \%$ of them managed to provide the correct answer. The meaning of the particle is abstract and there is a high likelihood that the students opted for the more literal meaning because it could also have made sense. The phrasal verb to work out has, alongside many other phrasal verbs, a variety of meanings.

6. The cost of eating out is quite high here.

a) extinction b) extension c) physically outside d) mentally go beyond

In total, $80 \%$ of the students were able to identify the correct answer, presumably due to the fact that out had a very literal meaning in this phrasal verb.

The options that were provided for the particle in are as follows: 1) participation/contribution 2) understanding/acquisition 3) effect 4) being physically inside.

7. We all chipped in so that we could afford a really expensive present.

a) understanding/acquisition b) participation/contribution c) being physically inside d) effect

The students apparently had much more difficulty identifying the appropriate answer. It would be logical to assume that the reason why only $40 \%$ 
of them were able to come up with the appropriate answer lies in the nature of the particle's abstract meaning.

8. It was quite an interesting lecture but there was just too much to take in.

a) understanding/acquisition b) participation/contribution c) being physically inside d) effect

A very low percentage of them $(30 \%)$ were capable of deciding on the correct option. The opaque nature of the particle's meaning is most probably the primary reason as to why only 3 students tackled this sentence in an appropriate manner.

9. It takes about half an hour for the tablets to kick in.

a) understanding/acquisition b) participation/contribution c) being physically inside $\boldsymbol{d})$ effect

Only 4 students (40\%) guessed the right meaning, probably due to high idiomaticity.

10. They broke in through the kitchen window.

a) understanding/acquisition b) participation/contribution c) being physically inside d) effect

Seventy percent were correct. The meaning of this particle is very transparent.

\subsubsection{The control group (part 2)}

The questions in part 2 also came with four options. Five sentences were provided, and each contained a phrasal verb. These were all the options that were provided: 1) to understand something 2) very easy to notice 3 ) to make something continue for longer than is usual or necessary 4) to start to have an effect 5) to give an amount of money, especially to pay for something together.

The sentences with their analysis will now be listed:

1. She's new to the job and it really sticks out.

a) to understand something $\boldsymbol{b}$ ) very easy to notice c) to make something continue for longer than is usual or necessary d) to start to have an effect

Seventy percent of the students provided the correct answer. When compared to how efficient the students were in identifying the meaning of the particle in the same phrasal verb, it is obvious that they were more familiar with the meaning of the whole phrasal verb. The meaning of the whole unit was presented to them in class, whereas the meaning of the individual particle was not.

2. We couldn't work out why they looked so guilty. 
a) to understand something $b$ ) to notice something very easily c) to make something continue for longer than is usual or necessary d) to start to have an effect

Seventy percent guessed the right answer. There is a distinct difference between the percentage of the correct answers for the whole phrasal verb, and for the particle (30\%). Again, this can be ascribed to the fact that the students were directly exposed to whole phrasal verbs, without any focus on the particular meaning of the particles.

3. It takes about half an hour for the tablets to kick in.

a) to understand something $b$ ) to notice something very easily c) to make something continue for longer than is usual or necessary d) to start to have an effect

Sixty percent of the students knew the correct answer. When compared to the understanding of the particle (40\%), it is clear that the level of understanding is slightly higher.

4. The director drew the meeting out.

a) to understand something $b$ ) to notice something very easily c) to make something continue for longer than is usual or necessary d) to start to have an effect

Sixty percent of the students provided the correct answer, which is similar to the $60 \%$ for the particle.

5. We all chipped in so that we could get what we wanted.

a) to give an amount of money, especially to pay for something together b) to understand something $c$ ) to notice something very easily d) to make something continue for longer than is usual or necessary

A total of $60 \%$ of the students had correct answers, which is slightly better compared to the understanding of the very particle, which was $40 \%$.

\subsubsection{The experimental group (part 1)}

For question 1 (cross out), 80\% percent answered correctly with regard to the meaning of the particle. The meaning of the particle in this instance is not transparent, yet the results were very satisfactory. In question 2 (stick out), although the meaning of the particle is opaque, the number of the correct answers remained extremely high, with $90 \%$ of the students answering correctly. Question 3 (draw out) is the question with which the students were least successful, probably due to the phrasal verb's abstract meaning. Although the previous meanings were also not transparent, this seemed to be a problematic meaning, 
possibly due to the less common occurrence of this phrasal verb. Sixty percent identified the correct answer. Question 4 (die out) was an instance in which the students had less difficulty identifying the correct meaning of the particle. Eighty percent of them were successful. If the source of their knowledge regarding this question did not come from retention from class, it was certainly deduction from the context. Question 5 (work out) again proved to be relatively problematic, most certainly due to the multiple meanings of the particle out when combined with the verb work. Sixty percent of the students were correct. In question 6 (eat out), the students surprisingly had a low result, especially taking into account the fact that the particle had a very transparent meaning in the phrasal verb. In total, 70\% of them answered correctly. In question 7 (chip in), the results were unexpectedly high since the meaning of the particle is highly abstract. A total of $80 \%$ answered satisfactorily. In question 8 (take in), the results were again unexpectedly high. The meaning of the particle is not transparent. Nonetheless, $70 \%$ of them answered correctly. Question 9 (kick in) posed a problem for the students, since only $60 \%$ of them were able to identify the correct meaning of the particle. This came as no surprise to the researcher, owing to the fact that the particle was abstract in meaning. The students unexpectedly had relative difficulty with question 10 (broke in), which contained a particle that, in this context, had a transparent and a literal meaning. This could possibly be attributed to the fact that the students were already used to perceiving the particles as having a more abstract meaning.

\subsubsection{The experimental group (part 2)}

For question 1 (stick out), the meaning of the phrasal verb did not seem to cause difficulty for the students, since $80 \%$ of them successfully completed this task. With question 2 (work out), the students again had no greater difficulty reaching the correct answer. In total, $80 \%$ knew the meaning of the phrasal verb. Question 3 (kick in) was done with relative ease, since $70 \%$ of the student identified the adequate meaning. Question 4 was the most problematic one of all. Only $60 \%$ managed to retain the meaning of the phrasal verb in the short run. Question 5 can be said to have been answered with a satisfactory percentage. Eighty percent of them were correct. 


\subsection{The delayed test}

\subsubsection{The control group}

The untaught phrasal verbs proved to be quite problematic for the students of the control group (46\%). Question 1 was completed with a poor result $(40 \%)$.

1. The spices really bring out the flavour of the meat.

a) to understand something $\boldsymbol{b})$ very easy to notice, emphasise c) to make something continue for longer than is usual or necessary d) to start to have an effect

Question 2 was done slightly better than the previous one, with $50 \%$ correct answers.

2. Women. I just can't figure them out.

a) to understand something $b$ ) to notice something very easily c) to make something continue for longer than is usual or necessary d) to start to have an effect

Question 3 (set in) was done in a similar fashion (50\%).

3. It was when I realised how many people I was speaking to that the panic set in.

a) to understand something $b$ ) to notice something very easily $c$ ) to give an amount of money, especially to pay for something together d) to start to have an effect

Question 4 proved to be the easiest one for the students, with $70 \%$ correct answers.

4. Profits were falling until the bookstore branched out into selling CDs.

a) to extend your activities $b)$ to notice something very easily $c$ ) to understand something d) to start to have an effect

Question 5 was, by far, the most challenging one for the participants and they did it with an accuracy rate of $20 \%$.

5. If we all muck in, we could get the whole house painted by the end of the week.

a) to participate in something b) to understand something $c$ ) to notice something very easily d) to make something continue for longer than is usual or necessary 


\subsubsection{The experimental group}

The results of the participants for this key section of the research were considerably high $(62 \%)$.

In question 1 (bring out), the students were successful, with $70 \%$ of the answers correct. The second question (figure out) contained a phrasal verb that was quite idiomatic, and, therefore, proved to be difficult to answer (60\%). This is where the students were expected to apply their newly-acquired knowledge of thinking about the basic meaning of the particle and discover the meaning of the whole particle. However, although the phrasal verb itself was idiomatic, it is by far the most frequently used one of all the phrasal verbs given to the students in this section. This is why the results are unexpectedly low for the phrasal verb at hand. One possible explanation is that the students were confused by the answers provided and that they confused this phrasal verb with another one. Question 3 (set in) was quite idiomatic, but the students still managed to guess the meaning of the phrasal verb, supposedly by relying on the new approach. Question 4 (branch out) was done with relative success (60\%). The fifth question (muck in) was undoubtedly the most problematic one for the students. Only $40 \%$ of the answers were correct.

\subsection{The comparison of the control and experimental group in the} immediate test

When the results of the control and experimental group are taken into account, it immediately becomes clear that the experimental group did considerably better with regard to the comprehension of particles, and slightly better with phrasal verbs, which can be observed in Table 1 and Table 2.

\begin{tabular}{|c|c|c|c|c|c|}
\hline Ques. & Stud. & Control group \% & Experimental group \% & Ques. & Stud. \\
\hline 1 & C1 & 60 & 80 & 1 & E1 \\
\hline 2 & C2 & 50 & 90 & 2 & E2 \\
\hline 3 & C3 & 60 & 60 & 3 & E3 \\
\hline 4 & C4 & 70 & 80 & 4 & E4 \\
\hline 5 & C5 & 30 & 60 & 5 & E5 \\
\hline 6 & C6 & 80 & 70 & 6 & E6 \\
\hline 7 & C7 & 40 & 80 & 7 & E7 \\
\hline 8 & C8 & 30 & 70 & 8 & E8 \\
\hline 9 & C9 & 40 & 60 & 9 & E9 \\
\hline 10 & C10 & 70 & 70 & 10 & E10 \\
\hline
\end{tabular}


Final score

53

72

Final score

Table 1: The Students' Results from the Control and Experimental Group (part 1) Immediate Test

In part 1, the results of the control group were quite unsatisfactory (53\%), while the performance of the experimental group was unexpectedly much more efficient. Seventy-two percent of them were able to guess the meanings of the particles in different contexts. The task itself was remarkably challenging, primarily due to the abstract nature of the majority of the particles. It is obvious that the accuracy of the answers rises in accordance with the degree of transparency. Those phrasal verbs that were extremely opaque in their meaning (work out, take in, kick in) posed the biggest problem for the participants of the control group. The meanings of the particles in phrasal verbs such as eat out and break in were not so problematic. Only student C7 was able to obtain $100 \%$ of the correct answers in this part of the test.

If the same is observed for part 1 in the experimental group, a similar pattern can be perceived, but with obvious differences. The more transparent meanings of the particles did not seem to pose a big problem for the students of the experimental group, but neither did the more opaque ones. Particles such as cross out, stick out and chip in were understood with even greater accuracy. The conclusion that ensues from such a fact is that the students were even more focused on these abstract meanings since special attention was placed on the possible variety of meanings of these particles. The overall observation regarding part 1 is that the nature of presenting the wide range of meanings of the particles must have inevitably led to the students comprehending the matter to a large extent. Students E3, E6, E8 and E10 had 100\% in this first part, which ultimately reflects the systematic coverage of this grammatical unit, unlike the control group, in which only student $\mathrm{C} 7$ was able to attain the highest number of points. If one considers that the students of the control group got absolutely no instruction on the separate meanings of the particles, even this one student's achievement should be taken as a great success on his/her part.

\begin{tabular}{|c|c|c|c|c|c|}
\hline Ques. & Stud. & Control group \% & Experimental group \% & Ques. & Stud. \\
\hline 1 & C1 & 70 & 80 & 1 & E1 \\
\hline 2 & C2 & 70 & 80 & 2 & E2 \\
\hline 3 & C3 & 60 & 70 & 3 & E3 \\
\hline
\end{tabular}




\begin{tabular}{|c|c|c|c|c|c|}
\hline 4 & C4 & 60 & 60 & 4 & E4 \\
\hline 5 & C5 & 60 & 80 & 5 & E5 \\
\hline \multicolumn{2}{|c|}{ Final score } & $\mathbf{6 4}$ & $\mathbf{7 4}$ & \multicolumn{3}{|c|}{ Final score } \\
\hline
\end{tabular}

Table 2: The Students' Results from the Control and Experimental Group (part 2) Immediate Test

When part 2 is analysed, the control group obtained solid results (64\%). This is significantly higher in contrast with their performance in part 1 . They were expected to remember the Serbian translations that were directly given to them, and match them with the appropriate English meanings. Once the results of part 1 and part 2 are compared, it is clear that there is no correlation between the ability to understand the separate particle and the whole phrasal verb. To clarify, when they had difficulty comprehending the meaning of the particle out in work out, this did not necessarily imply that they had trouble understanding the phrasal verb work out as a whole. This further suggests that the students did not take into account the meaning of the separate particle when tackling the meaning of the whole phrasal verb, and that they saw these two parts as two completely independent tasks.

In part 2, the experimental group did slightly better than the control group, since it achieved $74 \%$. While the discrepancy between the results obtained in part $1(53 \%)$ and part $2(64 \%)$ is more conspicuous, such a trend is not present in the experimental group, with this discrepancy being almost non-existent $(72 \%$ vs. $74 \%$ ). If the participants of the experimental group had relative difficulty comprehending the meaning of a certain particle (e.g. out in draw out) this was evident in understanding the meaning of that same phrasal verb as well. In other words, the students of the experimental group were considering the meaning of the separate particle when concluding about the meaning of the whole phrasal verb.

3.4. The comparison of the control and experimental group in the delayed test

The essence of the delayed test was to establish the extent to which the approach of cognitive linguistics was efficient when put to use with untaught phrasal verbs. The results can be observed in Table 3.

\begin{tabular}{|c|c|c|c|c|c|}
\hline Ques. & Stud. & Control group \% & Experimental group \% & Ques. & Stud. \\
\hline 1 & C1 & 40 & 70 & 1 & E1 \\
\hline
\end{tabular}




\begin{tabular}{|c|c|c|c|c|c|}
\hline 2 & C2 & 50 & 60 & 2 & E2 \\
\hline 3 & C3 & 50 & 80 & 3 & E3 \\
\hline 4 & C4 & 70 & 60 & 4 & E4 \\
\hline 5 & C5 & 20 & 40 & 5 & E5 \\
\hline \multicolumn{2}{|c|}{ Final score } & $\mathbf{4 6}$ & $\mathbf{6 2}$ & Final score \\
\hline
\end{tabular}

Table 3: The Students' Results from the Control and Experimental Group (untaught phrasal verbs) - Delayed Test

The control group had difficulty guessing the correct meanings of unfamiliar phrasal verbs, which can be concluded based on the poor result of $46 \%$. It is evident that the students did not benefit much from the traditional approach of providing direct Serbian translations as equivalents. Contrasting this with the results collected from the experimental group, a difference in the response is undoubtedly apparent. Although the results themselves were not so high when the cognitive approach was applied (62\%), they were still distinctly higher than the ones in the control group. The conclusion that could be reached is that thinking about the meaning of phrasal verbs by considering the metaphorical meanings of the particles must have played a beneficial role in the final outcome of the research.

\section{CONCLUSION}

The essential characteristic of the cognitive approach is that semantics and associations should be involved in the process of deciphering the meaning of phrasal verbs, without trying to memorise the direct Serbian translation (equivalent). The phrasal verbs discussed in this research all contained only a limited number of particles. If a link between the more literal and metaphorical meanings of particles is sought for, one can see that there is considerable similarity between these seemingly unrelated meanings. The meanings of phrasal verbs that are more metaphorical and opaque in meaning can be remembered much more easily if their meaning is compared to more literal phrasal verbs. The three hypotheses all proved to be correct. The first one was that the experimental group, which was exposed to the cognitive linguistic approach, would be able to understand the meaning of familiar (taught) phrasal verbs better than the control group. The second hypothesis was that those students who had a better understanding of the separate meanings of particles would automatically display a better knowledge of whole phrasal verbs because they would be thinking about the metaphorical meaning hidden behind the phrasal verbs and remember them 
longer. This was also proven, since the students from the experimental group performed better in the exercise with separate particles in the immediate test (72\% vs. 53\%). The results concerning the exercise with separate particles and whole phrasal verbs were congruent, with few discrepancies in the experimental group. On the other hand, there was a significant discrepancy in the results obtained in the control group between the exercise with separate particles and whole phrasal verbs. The students of the control group did not have an insight into the meanings of particles and were, therefore, unable to utilise that knowledge in constructing the meaning of phrasal verbs. Consequently, the results in the control group in part 2 were not as high as in the experimental group (74\% vs. 64\%). The final hypothesis that was pre-defined was that the experimental group would obtain a higher score than the control group in the section of the delayed test that dealt with unfamiliar (untaught) phrasal verbs. The assumption turned out to be correct (62\% vs. $46 \%$ ), proving that the cognitive linguistic approach had made it easier for the students of the experimental group to decompose the phrasal verbs to their integral units and think about how a more metaphorical meaning can be linked to a more literal one. By finding such analogies and going to the root meaning, one finds it more meaningful to understand and remember phrasal verbs, including those that are unfamiliar to the student.

\section{REFERENCES}

Cambridge International Dictionary of Phrasal Verbs. (1997). Cambridge: Cambridge University Press.

Crystal, D. (1980). A First Dictionary of Linguistics and Phonetics. Cambridge: Cambridge University Press.

Evans, V, Bergen, B. K, Zinken, J. (2007). "The Cognitive Linguistics Enterprise: An Overview", in The Cognitive Linguistics Reader, ed. V. Evans, B. K. Bergen \& J. Zinken (London: Equinox): 1-36.

Ganji, M. (2011). "The Best Way to Teach Phrasal Verbs: Translation, Sentential Contextualization or Metaphorical Conceptualization?", Theory and Practice in Language Studies 1(11): 1497-1506.

Kovacs, É. (2011). "The Traditional Vs. Cognitive Approach to English Phrasal Verbs". Publicationes Universitatis Miskolcinensis. Sectio Philosophica 16 (1): 141-160.

Marks, J. (2005). "Phrasaled out? Don't worry! Help is at hand", in MED Magazine Issue 32. Accessed 15 June 2009. URL: http://www.macmillandictionary.com/MEDMagazine/july-2005/32-Feature-Phrasaled-out.htm2005.

Moon, R. (2005). "Metaphor and Phrasal Verbs", in Macmillan Phrasal Verbs Plus. Language Study, ed. M. Rundell (Oxford: Bloomsbury Publishing): LS 5.

Morgan, P. S. (1997): "Figuring Out Figure Out: Metaphor and the Semantics of the English 
Verb-Particle Construction". Cognitive Linguistics 8(4): 327-357.

Tyler, A. \& Evans, V. (2004). "Applying Cognitive Linguistics to Pedagogical Grammar: The Case of Over", in Cognitive Linguistics, Second Language Acquisition, and Foreign Language Teaching, ed. M. Achard \& S. Niemeier (Berlin: Mouton de Gruyter): 257-280.

Srđan M. Gajdoš

\section{PODUČAVANJE SRPSKIH UČENIKA ENGLESKIM FRAZNIM GLAGOLIMA: TRADICIONALNI PRISTUP U KONTRASTU SA PRISTUPOM KOGNITIVNE LINGVISTIKE}

Sažetak

Frazni glagoli predstavljaju problematičnu nastavnu jedinicu kako za nastavnike tako i za učenike. Frazni glagoli mogu imati prozirno i nepozirno značenje, zavisno od značenja glagolskog dela, a još više od značenja same partikule. Istraživanje se bavi opštim principima kognitivne lingvistike, sa posebnim akcentom na frazne glagole i način na koji se oni u datom polju obrađuju. Istraživanje analizira dobijene rezultate nakon korišćenja tradicionalnog i kognitivističkog pristupa u nastavi. U kontrolnoj grupi korišćen je tradicionalni pristup u podučavanju fraznih glagola - istraživač je davao direktne prevode za ove jedinice, bez obaziranja na osnovno (dubinsko) značenje partikula. Frazali su posmatrani više kao kompleksna jezička pojava koja se može usvojiti i razumeti samo kroz učenje napamet. U eksperimentalnoj grupi istraživač je predstavio frazne glagole stavljanjem akcenta na značenje samih partikula i traženjem veze između osnovnog i njegovih izvedenih značenja. Na primer, partikula out, koja označava spoljašnjost, tumačena je u svetlu navedenog značenja, čak i kada je razvijala izvedena značenja kao što su: isključivanje, izumiranje, izduživanje i umiranje. Tražena je značenjska veza između osnovnog i razvijenih značenja. Autor je testirao obe grupe na kraju časa. Obe grupe su testirane i nakon tri nedelje kako bi se ustanovilo njihovo razumevanje neobrađenih fraznih glagola. Nakon upoređivanja rezultata testiranja, autor je zaključio da su polaznici uspešnije savladali frazne glagole kad su bili podučavani kognitivističkim metodom (i dugoročno i kratkoročno). Zaključeno je da su polaznici kojima je skrenuta pažnja na raznovrsna značenja partikula mogli bolje da razumeju značenje fraznih glagola kao celine. Ustanovljeno je, takođe, da su polaznici eksperimentalne grupe, koji su bili podvrgnuti kognitivističkom pristupu, mogli bolje da prepoznaju značenje nepoznatih fraznih glagola.

Ključne reči: frazni glagoli, partikule, tradicionalni pristup, kognitivistički pristup, prevođenje, metaforička konceptualizacija, neprozirno značenje, prozirno značenje.

Primljeno: 6.10.2016.

Prihvaćeno: 21.11.2016. 